\title{
HUBUNGAN POLA KONSUMSI ZAT GIZI MAKRO DAN MIKRO DENGAN TEKANAN DARAH PADA PENDERITA HIPERTENSI
}

\author{
Listiana, Arie krisnasary, Ahmad Rizal \\ Politeknik Kesehatan Kementerian Kesehatan Bengkulu, Jurusan Gizi, \\ Jalan Indragiri Nomor 03 Padang Harapan Bengkulu \\ Email :jmkbengkulu@gmail.com
}

\begin{abstract}
Hypertension is a condition that shows a person's blood pressure $\geq 140 \mathrm{mmHg}$ for systolic and / or $\geq 90 \mathrm{mmHg}$ pressure for diastolic pressure. The purpose of this research is to know the correlation between consumption pattern of macro and micro nutrients to blood pressure of hypertension patient in RSUD dr.M.Yunus Bengkulu Year 2017. Method: This research is an analytic survey, with cross sectional design. The location of this research is in poly disease in RSUD dr.M.Yunus. Samples were hypertension patients who treated in poly disease in RSUD Dr.M.Yunus Bengkulu as many as 50 samples, taken with chi square technique. Data of macro and micro nutrient intake was obtained through form food frequency questioner (FFQ). The data obtained were analyzed using chi square test. There is no association of protein with hypertension, no association of fat with hypertension, no carbohydrate relationship with hypertension, no sodium relationship with hypertension, no calcium relationship with hypertension, no potassium relationship with hypertension, no magnesium relationship with hypertension, no there is correlation of fiber with hypertension, there is no correlation of vitamin D with hypertension in RSUD dr.M.Yunus Kota Bengkulu year 2017. There is no correlation of consumption pattern of macro and micro nutrients with blood pressure in hypertension patient in poly disease in RSUD Dr.M. Yunus bengkulu in 2017. The need for an active family role related to the motivation and diet of hypertensive patients
\end{abstract}

Keywords: Macro nutrient, Micro, blood pressure of hypertension patient

\begin{abstract}
Abstrak: Hipertensi merupakan suatu keadaan yang menunjukkan tekanan darah seseorang $\geq 140 \mathrm{mmHg}$ untuk tekanan sistolik dan atau $\geq 90 \mathrm{mmHg}$ untuk tekanan diastolik. Tujuan penelitian untuk mengetahui hubungan pola konsumsi zat gizi makro dan mikro terhadap tekanan darah penderita Hipertensi di RSUD dr.M.Yunus Bengkulu Tahun 2017. Metode : Penelitian ini merupakan survei analitik, dengan desain cross sectional. Lokasi penelitian ini di poli penyakit dalam RSUD dr.M.Yunus. Sampel adalah pasien hipertensi yang berobat di poli penyakit dalam RSUD Dr.M.Yunus Bengkulu sebanyak 50 sampel, yang diambil dengan teknik chi square. Data asupan zat gizi makro dan mikro diperoleh melalui form food frequency questioner (FFQ). Data yang diperoleh dianalisis menggunakan uji chi square. Tidak ada hubungan protein dengan hipertensi, tidak ada hubungan lemak dengan hipertensi, tidak ada hubungan karbohidrat dengan hipertensi, tidak ada hubungan natrium dengan hipertensi, tidak ada hubungan kalsium dengan hipertensi, tidak ada hubungan kalium dengan hipertensi, tidak ada hubungan magnesium dengan hipertensi, tidak ada hubungan serat dengan hipertensi, tidak ada hubungan vitamin D dengan hipertensi di RSUD dr.M.Yunus Kota Bengkulu tahun 2017.Tidak ada hubungan pola konsumsi zat gizi makro dan mikro dengan tekanan darah pada penderita hipertensi di poli penyakit dalam RSUD Dr.M.Yunus bengkulu tahun 2017. Perlunya peran aktif kelurga terkait motivasi dan pola makan pasien hipertensi
\end{abstract}

Kata Kunci: Zat gizi makro, Mikro, tekanan darah penderita hipertensi

Hipertensi atau yang lebih dikenal dengan penyakit tekanan darah tinggi adalah suatu keadaan seseorang mengalami peningkatan tekanan darah diatas normal yang mengakibatkan peningkatan angka 
kesakitan (morbiditas) dan angka kematian (mortalitas) (Dalimartha dkk, 2008).

Kematian akibat hipertensi didunia beradap ada peringkat 29 dari 172 negara dengan prevalensi sebesar $25,26 \%$ dan menempati peringkat ke 7 sebagai penyebab kematian di Indonesia. Untuk kawasan ASEAN, negara Indonesia merupakan peringkat tertinggi kedua setelah negara Philipina. Saat ini hipertensi merupakan tantangan besar di Indonesia karena merupakan kondisi yang sering ditemukan pada pelayanan kesehatan primer World Health Organization (WHO) (2014).

Faktor-faktor yang mempengaruhi hipertensi dibagi menjadi dua kelompok yaitu faktor yang melekat atau tidak dapat diubah seperti jenis kelamin, umur, genetik dan faktor yang dapat diubah seperti pola makan, kebiasaan olah raga dan lain-lain. Faktor-faktor asupan yang mempengaruhi hipertensi adalah konsumsi makanan yang asin, konsumsi makanan yang manis, berlemak dan minuman berkafein. Pola konsumsi sumber protein nabati berhubungan dengan penurunan tekanan darah, sedangkan sumber protein hewani tidak berpengaruh terhadap tekanan darah (Apple,LJ 2006). Asupan lemak yang tinggi dapat meningkatkan kadar lemak di dalam darah dan mengakibatkan terbentuknya plak. Plak tersebut akan berkembang menjadi arterosklerosis yang mengakibatkan tidak elastisitas pembuluh darah sehingga terjadinya penyempitan pada tahanan aliran darah koroner yang menyebabkan naiknya tekanan darah (Widyaningrum, 2012).

Pola konsumsi karbohidrat yang tinggi kalori dari kelompok tinggi kalori dari kelompok karbohidrat monosakarida (glucose, fructose, galactose dan lactose) ternayata juga dapat meningkatkan tekanan darah (Shils ME 2006). Menurut Karppanen (2016), pengurangan asupan natrium dapat menurunkan tekanan darah sistolik sebesar>10 $\mathrm{mmHg}$ dan $75-80 \%$ dapat menurunkan tingkat kematian stroke dan jantung koroner. Kalsium juga berperan dalam menurunkan tekanan darah. Menurut Houston (2008) meningkatkan asupan mineral seperti kalium, kalsium dapat menurunan tekanan darah dan mengurangi kejadian hipertensi.

Magnesium merupakan salah satu mineral yang berperan penting bagi kesehatan dan sistem metabolisme tubuh. Hasil studi memberikan suplementasi magnesium untuk mengobati hipertensi telah menjadi kontradiksi. Konsumsi tinggi serat berhubungan dengan tekanan darah, buah-buahaan, sayuran, kalium, vitamin $\mathrm{C}$ serta konsumsi makanan yang sehat dan bergizi dapat mencegah dan mengobati hipertensi (Utsugi, 2008). Menurut Borgie (2015), Konsumsi buah dan sayuran dalam jangka panjang dapat mengurangi risiko terjadinya hipertensi. Penelitian pada penderita hipertensi menunjukkan bahwa mereka yang terpapar dengan sinar ultraviolet selama 3 bulan mengalami peningkatan konsentrasi

vitamin D aktif pada aliran darahnya sebesar $180 \%$. Akibatnya, terjadi penurunan tekanan darah diastolik dan sistolik, masing-masing sebesar $6 \mathrm{mmHg}$.

\section{BAHAN DAN CARA KERJA}

Desain penelitian yang digunakan adalah survei analitik yaitu, penelitian yang digunakan untuk mengetahui bagaimana dan mengapa fenomena kesehatan tersebut terjadi. Rancangan peneltian yang digunakan dalam penelitian ini adalah cross-sectional. Sampel dalam penelitian ini sebanyak 50 sampel dengan cara pengambilan sampel menggunakan teknik probability sampling yang sudah sesuai kriteria yang diinginkan. Data primer terlebih meliputi zat gizi makro dan mikro dengan tekanan darah penderita hipertensi yang diperoleh anamnesa, wawancara dan observasi kepada pasien dan kelurganya secara langsung. Data sekunder diperoleh dari bagian rekam medik di RSUD Dr.M.Yunus Bengkulu tahun 2017. 
Data asupan pola konsumsi zat gizi makro dan mikro dengan tekanan darah penderita hipertensi yang telah terkumpul selanjutnya diolah dan dianalisis.Uji statistik yang digunakan adalah analisis univariat variabel yang diteliti menggunakan distribusi frekuensi dan analisis bivariat. Analisis bivariat bertujuan

\section{HASIL}

\section{Analisa Univariat}

Tabel 1. Gambaran Konsumsi Zat Gizi Makro Dan Mikro dan Tekanan Darah Penderita Hipertensi di Poli Penyakit Dalam RSUD Dr.M. Yunus Bengkulu

\begin{tabular}{|c|c|c|}
\hline $\begin{array}{c}\text { Gambaran konsumsi } \\
\text { zat gizi makro dan } \\
\text { mikro }\end{array}$ & $\begin{array}{l}\text { Frekuensi } \\
\text { (n) }\end{array}$ & $\begin{array}{l}\text { Persentase } \\
\quad(\%)\end{array}$ \\
\hline \multicolumn{3}{|l|}{ Hipertensi } \\
\hline Hipertensi & 25 & 50,0 \\
\hline Tidak hipertensi & 25 & 50,0 \\
\hline \multicolumn{3}{|l|}{$\begin{array}{l}\text { Pola Pola konsumsi } \\
\text { protein }\end{array}$} \\
\hline Sering & 33 & 66 \\
\hline Jarang & 17 & 34 \\
\hline \multicolumn{3}{|l|}{ Pola konsumsi lemak } \\
\hline Sering & 15 & 30 \\
\hline Jarang & 35 & 70 \\
\hline \multicolumn{3}{|l|}{$\begin{array}{l}\text { Pola konsumsi } \\
\text { karbohidrat }\end{array}$} \\
\hline Sering & 22 & 44 \\
\hline Jarang & 28 & 56 \\
\hline \multicolumn{3}{|l|}{ Pola konsumsi natrium } \\
\hline Sering & 15 & 70 \\
\hline Jarang & 35 & 30 \\
\hline \multicolumn{3}{|l|}{ Pola konsumsi kalsium } \\
\hline Sering & 6 & 12 \\
\hline Jarang & 44 & 88 \\
\hline \multicolumn{3}{|l|}{ Pola konsumsi kalium } \\
\hline Sering & 25 & 50 \\
\hline Jarang & 25 & 50 \\
\hline \multicolumn{3}{|c|}{ Pola konsumsi magnesium } \\
\hline Sering & 27 & 54 \\
\hline Jarang & 25 & 46 \\
\hline \multicolumn{3}{|l|}{ Pola konsumsi serat } \\
\hline Sering & 19 & 38 \\
\hline Jarang & 31 & 62 \\
\hline \multicolumn{3}{|c|}{ Pola konsumsi vitamin D } \\
\hline Sering & 13 & 26 \\
\hline Jarang & 37 & 74 \\
\hline
\end{tabular}

Berdasarkan tabel 1 uji statistik menggunakan chi-square bahwa pola konsumsi protein pasien hipertensi dan tidak hipertensi hampir sebagian pasien sering mengkonsumsi bahan makanan yang mengandung protein sebanyak $66 \%$ untuk mengetahui hubungan antara variabel independen asupan zat gizi makro dan mikro dengan tekanan darah dengan variabel dependen kejadian penyakit hipertensi yang masing-masing variabel berskala ordinal menggunakan uji chisquare.

(33 orang). Hampir sebagian pasien sering mengkonsumsi bahan makanan yang mengandung lemak sebanyak 30\% (15 orang). Hampir sebagian pasien sering juga mengkonsumsi bahan makanan yang mengandung karbohidrat sebanyak $44 \%$ (22 orang). Sebagian kecil pasien sering mengkonsumsi bahan makanan yang mengandung natrium sebanyak $70 \%$ (15 orang). Sebagian kecil pasien sering mengkonsumsi bahan makanan yang mengandung kalsium sebanyak $12 \%$ (6 orang). Setengah pasien sering mengkonsumsi bahan makanan yang mengandung kalium sebanyak 50\% (25 orang). Sebagian pasien sering mengkonsumsi bahan makanan yang mengandung magnesium sebanyak 54\% (27 orang). Hampir sebagian pasien sering mengkonsumsi bahan makanan yang mengandung serat sebanyak 38\% (19 orang). Dan hampir sebagian mengkonsumsi bahan makanan yang mengandung vitamin D sebanyak 26\% (13 orang).

\section{Analisa Bivariat}

Tabel 2. Hubungan Konsumsi Protein Dengan Kejadian Hipertensi di Poli Penyakit Dalam RSUD Dr.M.Yunus Bengkulu

\begin{tabular}{|c|c|c|c|c|c|}
\hline \multirow[b]{2}{*}{ Protein } & \multicolumn{2}{|c|}{$\begin{array}{c}\text { Kejadian } \\
\text { Hipertensi }\end{array}$} & \multirow[b]{2}{*}{ Total } & \multirow[t]{2}{*}{$\mathbf{P}$} & \multirow[t]{2}{*}{ OR } \\
\hline & $\begin{array}{c}\text { Hiper } \\
\text { tensi }\end{array}$ & $\begin{array}{c}\text { Tidak } \\
\text { Hiper- } \\
\text { tensi }\end{array}$ & & & \\
\hline Sering & 6 & 14 & 20 & & \\
\hline Jarang & $\begin{array}{c}35,3 \% \\
19 \\
57,6 \%\end{array}$ & $\begin{array}{c}42,4 \% \\
11 \\
647 \%\end{array}$ & $\begin{array}{c}100 \% \\
30 \\
100 \%\end{array}$ & 0,23 & 2,48 \\
\hline
\end{tabular}

Berdasarkan tabel 2. dapat dilihat bahwa dari 50 kejadian hipertensi dengan 
sering konsumsi protein 6 orang $(57,1 \%)$ terhadap penderita hipertensi, dan dari 50 kejadian hipertensi dengan jarang konsumsi protein adalah 19 orang $(57,6 \%)$. Berdasarkan uji statistik Chi-Square diperoleh nilai $\mathrm{p}=0.232$ ( $\mathrm{p}>0.005)$ yang berarti tidak ada hubungan yang bermakna antara konsumsi protein dengan tekanan darah pada penderita hipertensi di poli penyakit dalam RSUD dr. M. Yunus Bengkulu.

Tabel 3. Hubungan Konsumsi Lemak Dengan Kejadian Hipertensi Di Poli Penyakit dalam RSUD Dr.M.Yunus Bengkulu Tahun 2017

\begin{tabular}{|c|c|c|c|c|c|}
\hline \multirow[b]{2}{*}{ Lemak } & \multicolumn{2}{|c|}{$\begin{array}{l}\text { Kejadian } \\
\text { Hipertensi }\end{array}$} & \multirow[b]{2}{*}{ Total } & \multirow[t]{2}{*}{$\mathbf{P}$} & \multirow[t]{2}{*}{ OR } \\
\hline & $\begin{array}{c}\text { Hiper } \\
\text { tensi }\end{array}$ & $\begin{array}{c}\text { Tidak } \\
\text { Hiper- } \\
\text { tensi }\end{array}$ & & & \\
\hline Sering & 9 & 6 & 15 & & \\
\hline Jarang & $\begin{array}{c}60 \% \\
16 \\
45,7 \%\end{array}$ & $\begin{array}{c}40 \% \\
19 \\
54,3 \%\end{array}$ & $\begin{array}{c}100 \% \\
35 \\
100 \%\end{array}$ & $\mathbf{0 , 5 3 7}$ & 1,78 \\
\hline
\end{tabular}

Berdasarkan tabel 3. dapat dilihat bahwa dari 50 kejadian hipertensi dengan konsumsi lemak sering 9 orang $(60,7 \%)$ terhadap penderita hipertensi, dan dari 50kejadian hipertensi dengan konsumsi lemak jarang adalah 16 orang $(45,7 \%)$. Berdasarkan uji statistik Chi-Square diperoleh nilai $\mathrm{p}=0.537$ ( $\mathrm{p}>0.005)$ yang berarti tidak ada hubungan yang bermakna antara konsumsi lemak dengan tekanan darah pada penderita hipertensi di poli penyakit dalam RSUD dr. M. Yunus Bengkulu.

Tabel 4. Hubungan Konsumsi Karbohidrat Dengan Kejadian Hipertensi Di Poli Penyakit Dalam RSUD Dr.M.Yunus Bengkulu

\begin{tabular}{|c|c|c|c|c|c|}
\hline \multirow{2}{*}{$\begin{array}{l}\text { Karbo } \\
\text { hidrat }\end{array}$} & \multicolumn{2}{|c|}{$\begin{array}{l}\text { Kejadian } \\
\text { Hipertensi }\end{array}$} & \multirow[b]{2}{*}{ Total } & \multirow[t]{2}{*}{$\mathbf{P}$} & \multirow[t]{2}{*}{ OR } \\
\hline & $\begin{array}{c}\text { Hiper } \\
\text { tensi }\end{array}$ & $\begin{array}{c}\text { Tidak } \\
\text { Hiper- } \\
\text { tensi }\end{array}$ & & & \\
\hline Sering & 9 & 12 & 22 & & \\
\hline Jarang & $\begin{array}{c}40,9 \% \\
16 \\
57,1 \%\end{array}$ & $\begin{array}{c}59,1 \% \\
12 \\
42,9 \%\end{array}$ & $\begin{array}{c}100 \% \\
28 \\
100 \%\end{array}$ & 0,393 & $\mathbf{0 , 5 1}$ \\
\hline
\end{tabular}

Berdasarkan tabel 4. dapat dilihat bahwa dari dari 50 kejadian hipertensi dengan konsumsi karbohidrat sering 9 orang $(40,9 \%)$ terhadap penderita hipertensi, dan dari 50 kejadian hipertensi dengan konsumsi karbohidrat jarang adalah $16(57,1 \%)$. Berdasarkan uji statistik Chi-Square diperoleh nilai $\mathrm{p}=0,393(\mathrm{p}>0.005)$ yang berarti tidak ada hubungan yang bermakna antara asupan karbohidrat dengan tekanan darah pada penderita hipertensi di poli penyakit dalam RSUD dr M.Yunus Bengkulu.

Tabel 5. Hubungan Konsumsi Natrium Dengan Kejadian Hipertensi Di Poli Penyakit dalam RSUD Dr.M.Yunus Bengkulu Tahun 2017

\begin{tabular}{lccccc}
\hline & \multicolumn{2}{c}{$\begin{array}{c}\text { Kejadian } \\
\text { Hipertensi }\end{array}$} & & P & OR \\
\cline { 2 - 4 } Natrium & $\begin{array}{c}\text { Hiper } \\
\text { tensi }\end{array}$ & $\begin{array}{c}\text { Tidak } \\
\text { Hiper } \\
\text { tensi }\end{array}$ & & & \\
\hline Sering & 12 & 3 & 15 & & \\
& $80 \%$ & $20 \%$ & $100 \%$ & $\mathbf{0 , 1 4}$ & $\mathbf{6 , 7 6}$ \\
Jarang & 13 & 22 & 35 & & \\
& $37,1 \%$ & $62,9 \%$ & $100 \%$ & & \\
\hline
\end{tabular}

Berdasarkan tabel 5. dapat dilihat bahwa dari 50 kejadian hipertensi dengan konsumsi natrium sering 12 orang $(80 \%)$ terhadap penderita hipertensi, dan dari 50 kejadian hipertensi dengan konsumsi protein jarang adalah 13 orang $(37,1 \%)$. Berdasarkan uji statistik Chi-Square diperoleh nilai $\mathrm{p}=0,14 \quad(\mathrm{p}>0.005)$ yang berarti tidak ada hubungan yang bermakna antara konsumsi natrium dengan tekanan darah pada penderita hipertensi di poli penyakit dalam RSUD dr. M. Yunus Bengkulu.

Tabel 6. Hubungan Konsumsi Kalsium Dengan Kejadian Hipertensi Di Poli Penyakit Dalam RSUD Dr.M.Yunus Bengkulu

\begin{tabular}{|c|c|c|c|c|c|}
\hline \multirow[b]{2}{*}{ Kalsium } & \multicolumn{2}{|c|}{$\begin{array}{c}\text { Kejadian } \\
\text { Hipertensi }\end{array}$} & \multirow[b]{2}{*}{ Total } & \multirow[t]{2}{*}{$\mathbf{P}$} & \multirow[t]{2}{*}{ OR } \\
\hline & $\begin{array}{c}\text { Hipert } \\
\text { ensi }\end{array}$ & $\begin{array}{c}\text { Tidak } \\
\text { Hiper- } \\
\text { tensi }\end{array}$ & & & \\
\hline Sering & 4 & 2 & 6 & & \\
\hline Jarang & $\begin{array}{c}66,7 \% \\
21 \\
47,7 \%\end{array}$ & $\begin{array}{c}33,3 \% \\
23 \\
52,3 \%\end{array}$ & $\begin{array}{c}100 \% \\
44 \\
100 \%\end{array}$ & $\mathbf{0 , 3 9}$ & $\mathbf{0 , 5 1}$ \\
\hline
\end{tabular}

Berdasarkan tabel 6. dapat dilihat bahwa dari 50 kejadian hipertensi dengan 
sering konsumsi kalsium sering 4 orang $(66,7 \%)$ terhadap penderita hipertensi, dan dari 50 kejadian hipertensi dengan jarang konsumsi kalsium adalah 21 orang $(47,7 \%)$. Berdasarkan uji statistik ChiSquare diperoleh nilai $\mathrm{p}=0.663(\mathrm{p}>0.005)$ yang berarti tidak ada hubungan yang bermakna antara konsumsi kalsium dengan tekanan darah pada penderita hipertensi di poli penyakit dalam RSUD dr. M. Yunus Bengkulu.

Tabel 7. Hubungan Konsumsi Kalium Dengan Kejadian Hipertensi Di Poli Penyakit Dalam RSUD Dr.M.Yunus Bengkulu

\begin{tabular}{|c|c|c|c|c|c|}
\hline \multirow[b]{2}{*}{ Kalium } & \multicolumn{2}{|c|}{$\begin{array}{c}\text { Kejadian } \\
\text { Hipertensi }\end{array}$} & \multirow[b]{2}{*}{ Total } & \multirow[t]{2}{*}{$\mathbf{P}$} & \multirow[t]{2}{*}{ OR } \\
\hline & $\begin{array}{c}\text { Hipert } \\
\text { ensi }\end{array}$ & $\begin{array}{c}\text { Tidak } \\
\text { Hiper- } \\
\text { tensi }\end{array}$ & & & \\
\hline Sering & 13 & 12 & 25 & & \\
\hline Jarang & $\begin{array}{c}52 \% \\
12 \\
48 \%\end{array}$ & $\begin{array}{c}48 \% \\
13 \\
52 \%\end{array}$ & $\begin{array}{c}100 \% \\
25 \\
100 \%\end{array}$ & 0,10 & 1,17 \\
\hline
\end{tabular}

Berdasarkan tabel 7. dapat dilihat bahwa dari 50 kejadian hipertensi dengan sering konsumsi kalium 13 orang (52\%) terhadap penderita hipertensi, dan dari 50 kejadian hipertensi dengan jarangkonsumsi kalium adalah 12 orang (48\%). Berdasarkan uji statistik Chi-Square diperoleh nilai $\mathrm{p}=0.100 \quad(\mathrm{p}>0.005)$ yang berarti tidak ada hubungan yang bermakna antara konsumsi kalium dengan tekanan darah pada penderita hipertensi di poli penyakit dalam RSUD dr. M. Yunus Bengkulu.

Tabel 8. Hubungan Konsumsi Magnesium Dengan Kejadian Hipertensi Di Poli Penyakit Dalam RSUD Dr.M.Yunus Bengkulu

\begin{tabular}{|c|c|c|c|c|c|}
\hline \multirow{2}{*}{$\begin{array}{c}\text { Magnesi } \\
\text { um }\end{array}$} & \multicolumn{2}{|c|}{$\begin{array}{l}\text { Kejadian } \\
\text { Hipertensi }\end{array}$} & \multirow[b]{2}{*}{ Total } & \multirow[t]{2}{*}{$\mathbf{P}$} & \multirow{2}{*}{ OR } \\
\hline & $\begin{array}{c}\text { Hipert } \\
\text { ensi }\end{array}$ & $\begin{array}{l}\text { Tidak } \\
\text { Hiper } \\
\text {-tensi }\end{array}$ & & & \\
\hline Sering & 16 & 11 & 27 & & \\
\hline Jarang & $\begin{array}{c}59,3 \% \\
9 \\
391 \%\end{array}$ & $\begin{array}{c}40,7 \% \\
14 \\
60.9 \%\end{array}$ & $\begin{array}{c}100 \% \\
23 \\
100 \%\end{array}$ & 0,256 & 2,26 \\
\hline
\end{tabular}

Berdasarkan tabel 8. dapat dilihat bahwa dari 50 kejadian hipertensi yang sering mengkonsumsi magnesium16 orang $(59,3 \%)$ terhadap penderita hipertensi, dan dari 50 kejadian hipertensi dengan jarang konsumsi magnesium adalah 9 orang $(39,1 \%)$. Berdasarkan uji statistik ChiSquare diperoleh nilai $\mathrm{p}=0.256(\mathrm{p}>0.005)$ yang berarti tidak ada hubungan yang bermakna antara konsumsi magnesium dengan tekanan darah pada penderita hipertensi di poli penyakit dalam RSUD dr. M. Yunus Bengkulu.

Tabel 9. Hubungan Konsumsi Serat Dengan Kejadian Hipertensi Di Poli Penyakit DalamRSUD Dr.M.Yunus Kota Bengkulu

\begin{tabular}{rccccc}
\hline & \multicolumn{2}{c}{$\begin{array}{c}\text { Kejadian } \\
\text { Hipertensi }\end{array}$} & & P & OR \\
\cline { 2 - 4 } Serat & $\begin{array}{c}\text { Hipert } \\
\text { ensi }\end{array}$ & $\begin{array}{c}\text { Tidak } \\
\text { Hiper- } \\
\text { tensi }\end{array}$ & & & \\
\hline Sering & 13 & 6 & 19 & & \\
& $68,4 \%$ & $31,6 \%$ & $100 \%$ & $\mathbf{0 , 0 8}$ & $\mathbf{3 , 4 3}$ \\
Jarang & 12 & 19 & 31 & & \\
& $38,7 \%$ & $61,3 \%$ & $100 \%$ & & \\
\hline
\end{tabular}

Berdasarkan tabel 9. dapat dilihat bahwa dari 50 kejadian hipertensi yang sering mengkonsumsi serat 13 orang $(68,4 \%)$ terhadap penderita hipertensi, dan dari 50 kejadian hipertensi dengan jarang konsumsi serat adalah 12 orang $(38,7 \%)$. Berdasarkan uji statistik Chi-Square diperoleh nilai $\mathrm{p}=0.080 \quad(\mathrm{p}>0.005)$ yang berarti tidak ada hubungan yang bermakna antara konsumsi serat dengan tekanan darah pada penderita hipertensi di poli penyakit dalam RSUD dr. M. Yunus Bengkulu.

Tabel 10. Hubungan Konsumsi Vitamin D Dengan Kejadian Hipertensi Di Poli Penyakit Dalam RSUD Dr.M.Yunus Bengkulu

\begin{tabular}{cccccc}
\hline \multirow{2}{*}{$\begin{array}{c}\text { Vitamin } \\
\text { D }\end{array}$} & \multicolumn{2}{c}{$\begin{array}{c}\text { Kejadian } \\
\text { Hipertensi }\end{array}$} & & P & OR \\
\cline { 2 - 4 } & $\begin{array}{c}\text { Hipert } \\
\text { ensi }\end{array}$ & $\begin{array}{c}\text { Tidak } \\
\text { Hiper- } \\
\text { tensi }\end{array}$ & & & \\
\hline Sering & 9 & 4 & 13 & & \\
Jarang & $69,2 \%$ & $30,8 \%$ & $100 \%$ & $\mathbf{0 , 1 9}$ & $\mathbf{2 , 9 5}$ \\
& 16 & 21 & 37 & $\mathbf{7}$ & \\
& $43,2 \%$ & $56,8 \%$ & $100 \%$ & & \\
\hline
\end{tabular}

Berdasarkan tabel 10. dapat dilihat bahwa dari 50 kejadian hipertensi yang 
sering mengkonsumsi vitamin D adalah 9 orang $(69,2 \%)$ terhadap penderita hipertensi, dan dari 50 kejadian hipertensi dengan jarang konsumsi vitamin $\mathrm{D}$ adalah 16 orang $(43,2 \%)$. Berdasarkan uji statistik Chi-Square diperoleh nilai $\mathrm{p}=0.197$

\section{PEMBAHASAN}

\section{Hubungan Konsumsi Protein dengan Tekanan Darah Penderita Hipertensi}

Hasil uji statistik menunjukan tidak adanya hubungan antara konsumsi lemak dengan tekanan darah dengan nilai $\mathrm{p}=0,232 \quad(\mathrm{p}>0,05)$. Penelitian ini tidak sejalan dengan penelitian Rista Emiria Afrida (2012) tentang asupan protein, lemak jenuh, natrium, serat dan IMT terkait dengan tekanan darah pasien hipertensi di RSUD Tugurejo Semarang yang menyatakan bahwa ada keterkaitan antara asupan protein dengan tekanan darah sistolik $(r=0.303 ; p=0.048)$ dan diastolik $(r=0.021 ; p=0.892)$. Penelitian ini tidak berhubungan karena, pada saat penentuan uji yang akan dilakukan terjadi kesalahan dalam menentukan uji. Seharusnya, uji yang dilakukan menggunakan uji case control, tetapi dilakukan uji cross sectional, sehingga hasil yang didapat tidak adanya hubungan konsumsi protein dengan tekanan darah penderita hipertensi.

Konsumsi protein dapat dilihat berdasarkan wawancara menggunakan FFQ yang didapatkan jenis protein yang sering dikonsumsi pasien yaitu ikan ,tempe, dan daging ayam 50 gr,tahu 100 gr, sebanyak 4-5 kali per minggu, kandungan ayam 50 gr adalah 13,4 gr, ikan 50 gr adalah $9,1 \mathrm{gr}$, tahu 100 gr adalah $8,1 \mathrm{gr}$, dan tempe 50 gr adalah 9,5 gr. Sedangkan porsi kecukupan 1 hari konsumsi protein berdasarkan Diet DASH untuk penderita hipertensi adalah 2 porsi atau kurang dari 2 kali per hari. Jadi konsumsi protein pada pasien ini melebihi kebutuhan sehari-hari.

Asupan protein pada penelitian ini sebagian besar bersumber dari protein
( $>0.005)$ yang berarti tidak ada hubungan yang bermakna antara konsumsi vitamin D dengan tekanan darah pada penderita hipertensi di poli penyakit dalam RSUD dr. M. Yunus Bengkulu.

nabati. Peneltian sebelumnya juga menunjukkan bahwa asupan protein nabati berkorelasi positif tidak bermakna dengan tekanan darah, tetapi hubungan yang tidak bermakna tersebut masih belum diketahui sebabnya. Sebagian besar makanan sumber protein nabati merupakan incomplete proteins. Incomplete proteins memiliki biological value yang rendah dan biasanya tidak menyediakan semua asam amino esensial atau menyediakan beberapa dari asam amino namun dalam jumlah yang terbatas.Sebaliknya, sumber protein hewani cenderung mengandung arginin, tirosin, leusin yang lebih tinggi dibanding protein nabati (Elliott, 2006).

Asam-asam amino memiliki peran yang penting dalam regulasi pembuluh darah (Martalina, 2012). Asam amino arginin, yang banyak terdapat pada sumber protein hewani seperti daging sapi, daging ayam, telur, sosis, jerohan, dan ikan yang meliputi ikan air tawar, asin dan tambak, bertindak sebagai substrat dari nitrit oxide (NO). Arginin dapat meningkatkan bioavaibilitas nitrit oxide (NO), yang bertindak sebagai vasodilator dan pengatur pertahanan vaskuler(Mitsumasa, 2009). Selain itu, mekanisme potensial L-arginin pada hipertensi adalah (1) meningkatkan fungsi vasomotor endothelial (2) meningkatkan sintesis nitrit oksida vaskuler (3) menurunkan aktivitas endotelin I dan angiotensin II (4) meningkatkan sensitifitas insulin Regulasi arginin dalam meningkatan sensitifitas insulin dari sel beta di pankreas dapat menekan pembentukan angiotensinogen oleh angiotensin II sehingga tidak terjadi vasokontriksi (Gocke, 2004). 


\section{Hubungan Konsumsi Lemak dengan Tekanan Darah Penderita Hipertensi}

Hasil uji statistik menunjukan tidak adanya hubungan antara konsumsi lemak dengan tekanan darah dengan nilai $p=0,537 \quad(p>0,05)$. Hal ini dikarenakan konsumsi lemak yang dilihat berdasarkan wawancara menggunakan FFQ semi kuantitatif, diketahui responden yang mengkonsumsi tinggi lemak hanya 4 orang saja, selebihnya responden kurang mengkonsumsi lemak yang tidak berhubungan dengan hipertensi. Penelitian ini tidak berhubungan karena, pada saat penentuan uji yang akan dilakukan terjadi kesalahan dalam menentukan uji. Seharusnya, uji yang dilakukan menggunakan uji case control, tetapi dilakukan uji cross sectional, sehingga hasil yang didapat tidak adanya hubungan konsumsi lemak dengan tekanan darah penderita hipertensi.

Makanan tinggi lemak yang sering dikonsumsipasien contoh nya susu sebanyak 10 gr 3 kali minum dalam sehari, kandungan lemak susu 20 gr adalah 0,4 gr sedangkan dianjurkan diet DASH dalam sehari mengkonsumsi susu hanya 8 ons untuk penderita hipertensi. Sehingga kebutuhan lemak melebihi konsumsi yang baik untuk satu hari bagi pasien hipertensi.

Hasil penelitian menggunakan FFQ semi kuantitatif juga menunjukan bahwa hanya sedikit pasien yang mengonsumsi makanan berlemak seperti daging ayam, daging sapi, ataupun daging kambing dikarenakan pasien membatasi makanan yang berlemak yang dapat memicu tekanan darah menjadi tinggi, selain itu pasien memang menderita penyakit penyerta lainnya seperti DM dan gout yang menjadi faktor pemicu tekanan darah sehingga pasien membatasi makanan yang dikonsumsi.

Semakin tinggi konsumsi makanan berlemak maka dapat berisiko terhadap hipertensi. Konsumsi lemak yang tinggi dapat meningkatkan kadar lemak di dalam darah dan mengakibatkan terbentuknya plak. Plak tersebut akan berkembang menjadi arterosklerosis yang mengakibatkan tidak elastisitas pembuluh darah sehingga terjadinya penyempitan pada tekanan aliran darah koroner yang menyebabkan naiknya tekanan darah (Widyaningrum, 2012).

Sargowo dkk (2011) mengatakan pengaruh komposisi asupan makan terhadap komponen sindrom metabolik pada remaja, menunjukkan bahwa terdapat hubungan antara komposisi asupan makan yang berlemak terhadap hipertensi. Dari hasil penelitian tersebut menunjukkan bahwa semakin banyak konsumsi makan berlemak, maka kejadian hipertensi semakin meningkat, oleh karena itu responden mengurangi makanan yang tinggi lemak yang terdapat di form FFQ semi kuantitatif seperti krim susu, keju, mentega, es krim dan ayam goreng.

Penelitian ini sejalan dengan Rawasiah dkk (2014) tentang hubungan faktor konsumsi makanan dengan kejadian hipertensi pada lansia di puskesmas Pattingallong menunjukkan bahwa tidak ada hubungan antara lemak dengan kejadian hipertensi.Penelitian yang dilakukan oleh Kartikasari (2012) di Desa Kabongan Kidul, Kabupaten Rembang menunjukkan bahwa konsumsi lemak tidak ada hubungan dengan peningkatan tekanan darah.

\section{Hubungan Konsumsi Karbohidrat dengan Tekanan Darah Penderita Hipertensi}

Hasil uji statistik menunjukan tidak adanya hubungan antara konsumsi lemak dengan tekanan darah dengan nilai $\mathrm{p}=0,393 \quad(\mathrm{p}>0,05)$. Penelitian ini tidak sejalan dengan penelitian Derris Sugianty (2008) tentang hubungan asupan karbohidrat, protein, lemak, natrium dan serat dengan tekanan darah pada lansia yang menyatakan bahwa ada hubungan antara asupan karbohidrat dengan tekanan darah sistolik $(r=0.288 ; p=0.039)$ dan diastolik $(r=0.363 ; p=0.008)$. Hal ini 
dikarenakan responden sudah terlebih dahulu membatasi makan setelah mengetahui menderita hipertensi, sehingga berdampak padaasupan karbohidrat responden, dan sebagian responden yang ke rumah sakit memiliki penyakit komplikasi lainnya, sehingga juga mempengaruhi asupan makan.

Penelitian ini tidak berhubungan karena, pada saat penentuan uji yang akan dilakukan terjadi kesalahan dalam menentukan uji. Seharusnya, uji yang dilakukan menggunakan uji case control, tetapi dilakukan uji cross sectional, sehingga hasil yang didapat tidak adanya hubungan konsumsi karbohidrat dengan tekanan darah penderita hipertensi.

Konsumsi makanan tinggi karbohidrat yang sering dikonsumsi pasien adalah nasi 3 porsi dalam 1 hari, sebanyak $100 \operatorname{gr}(1$ centong besar) energinya sebesar 79,5 gr sedangkan dianjurkan mengkonsumsi nasi hanya $1 / 2$ cangkir,sehingga kebutuhan pasien melebihi dari diet DASH untuk penderita hipertensi.

Komposisi makanan seperti karbohidrat diduga memiliki peran penting dalam kejadian tersebut, mengingat keduanya akan dimetabolisme menjadi trigliserid dan LDL (Low Density Lipoprotein) apabila kadarnya terlalu berlebihan. Karbohidrat adalah zat organik utama yang terdapat dalam tumbuhtumbuhan dan biasanya mewakili 50 sampai 75 persen dari jumlah bahan kering dalam bahan makanan ternak. Karbohidrat sebagian besar terdapat dalam biji, buah dan akar tumbuhan.

\section{Hubungan Konsumsi Natrium dengan Tekanan Darah Penderita Hipertensi}

Hasil uji statistik menunjukan bahwa tidak ada hubungan yang kuat antara konsumsi natrium dengan tekanan darah pada penderita hipertensi dengan nilai $p=0,14(p>0,05)$.Konsumsi natrium dapat dilihat berdasarkan wawancara menggunakan FFQ semi kuantitatif yang didapatkan 4 jenis makanan tinggi natrium yang sering dikonsumsi sebagian pasien yaitu kecap dan saos 20 gr 3-4 kali per hari, mie kering 4-5 kali seminggu. Kandungan natrium kecap dalam 20 gr adalah $1117,2 \mathrm{mg}$, saos $20 \mathrm{gr}$ adalah 2,8 mg konsumsi ini melebihi kebutuhan normal dalam sehari yang dianjurkan untuk mengkonsumsi natrium sebanyak $1500 \mathrm{mg}$.

Penelitian ini tidak berhubungan karena, pada saat penentuan uji yang akan dilakukan terjadi kesalahan dalam menentukan uji. Seharusnya, uji yang dilakukan menggunakan uji case control, tetapi dilakukan uji cross sectional, sehingga hasil yang didapat tidak adanya hubungan konsumsi natrium dengan tekanan darah penderita hipertensi.

Jumlah natrium tidak selaluberkaitan dengan hipertensi, karena hipertensi dapat disebabkan oleh faktor yang lain seperti stress, merokok, jenis kelamin, faktor lingkungan dan faktor genetik. Pendapat berbeda menyatakan bahwa penanganan yang tepat untuk hipertensi adalah diet rendah garam. Diet rendah garam pada hakekatnya merupakan diet dengan mengkonsumsi makanan tanpa garam dapur sama sekali dan mengurangi penggunaan bahan makanan yang tinggi natriumnya (Fauziah 2013)

Tidak adanya hubungan natrium dengan tekanan darah kemungkinan karena adanya keterbatasan dalam penelitian ini yaitu pada rerata asupan natrium pada subjek merupakan asupan natrium yang hanya berasal dari bahan makanan dan natrium yang ditambahkan saat pengolahan bahan makanan tanpa memasukkan rerata penambahan natrium yang digunakan subjek sebelum mengkonsumsi makanan McCulloughM (2010).

Tekanan darah tinggi terjadi bukan hanya karena asupan natrium yang tinggi pada saat ini melainkan manifestasi dari asupan natrium dalam jangka waktu yang lama. Hipertensi pada penelitian ini mungkin terjadi akibat kebiasaan yang sudah lama dilakukan oleh subjek untuk 
mengkonsumsi makanan tinggi natrium dan didukung oleh faktor -faktor lain yang dapat mempengaruhi tekanan darah (Krummel 2008).

Penelitian ini sejalan dengan peneltian Fatimah(2014), yang menyatakan bahwa tidak ada hubungan yang signifikan antara konsumsi natrium dengan tekanan darah pada mahasiswa UNHAS angkatan 2013 tahun 2014.

Penelitian ini sejalan dengan penelitian Mustamin (2010) yang mengatakan bahwa tidak terdapat hubungan yang bermakna antara asupan natrium dengan tekanan darah pada usia lanjut di Wilayah Puskesmas Bojo Baru Kabupaten Baru

\section{Hubungan Konsumsi Kalsium dengan Tekanan Darah Penderita Hipertensi}

Hasil uji statistik menunjukkan tidak adanya hubungan yang kuat antara konsumsi kalsium dengan tekanan darah dengan nilai $p=0,667(p>0,05)$. Hasil penelitian menggunakan FFQ semi kuantitatif menunjukan bahwa hanya sedikit pasien yang mengkonsumsi makanan yang mengandung kalsium sepertisusu bubuk(20gr), susu kental manis (20gr), dan keju dalam 1 bulan terakhir dikarenakan pasien takut mengkonsumsi bahan makanan yang mengandung tinggi lemak dan tinggi gula karena sebagian pasien menderita penyakit penyerta lainnya (komplikasi) seperti Diabetes Melitus yang dapat meningkatkan gula darahnya.

Penelitian ini tidak berhubungan karena, pada saat penentuan uji yang akan dilakukan terjadi kesalahan dalam menentukan uji. Seharusnya, uji yang dilakukan menggunakan uji case control, tetapi dilakukan uji cross sectional, sehingga hasil yang didapat tidak adanya hubungan konsumsi kalsium dengan tekanan darah penderita hipertensi.

Kandungan keju 20 gr adalah 9,2 mg sedangkan untuk kebutuhan sehari-hari adalah $1 \frac{1}{2}$ ons keju, konsumsi makanan tinggi kalsium ini memang kurang, karena itulah kalsium tidak berhubungan dengan hipertensi karena pasien memang membatasi makanan tinggi kalsium.

Keju mengandung kalsium tinggi, beberapa responden jarang mengkonsumsi keju yang hanya dikonsumsi 5 gr/bulan karena keju memiliki rasa asin sehingga responden berfikir mengkonsumsi keju dapat berpengaruh terhadap peningkatan tekanan darah. Beberapa responden juga mengurangi mengkonsumsi udang segar dan kepiting karena di dalam makanan tersebut mengandung kolesterol yang tinggi yang berakibat pada penyakit penyerta (komplikasi) lainnya yang dialami responden. Kolesterol jahat (LDL) akan menumpuk pada dinding pembuluh darah dan membentuk plak yang menjadikan pembuluh darah tidak elastis dan mengalami penyempitan sehingga tekanan aliran darah dalam pembuluh koroner akan naik dan memicu terjadinya hipertensi (Vilareal, 2008).

Kekurangan kalsium akan melemahkan kemampuan otot jantung untuk memompa darah. Hal ini akan berpengaruh terhadap tekanan darah. Jika asupan kalsium kurang dari kebutuhan tubuh maka untuk menjaga keseimbangan kalsium didalam darah, hormon paratiroid menstimulasi pengeluaran kalsium dari tulang dan masuk ke darah. Kalsium dalam darah akan mengikat asam lemak bebas sehingga pembuluh darah menjadi menebal dan mengeras sehingga dapat mengurangi elastisitas jantung yang akan meningkatkan tekanan darah.

Penelitian Etika hasna (2014) yang menyatakan bahwa tidak ada hubungan asupan kalsium dengan kejadian hipertensi mungkin dikaitkan dengan faktor lain seperti halnya faktor genetik individu yang bervariasi. Faktor genetik setiap individu juga mempengaruhi kemampuan tubuh menggunakan kalsium secara optimal untuk menurunkan tekanan darah dan adanya faktor -faktor yang menghambat absorbsi kalsium di usus halus seperti fosfor, oksalat dan serat yang masing - 
masing banyak terdapat dalam makanan berprotein tinggi, sayuran hijau, dan buah -buahan segar sehingga dapat menjadi penyebab tidak optimalnya fungsi kalsium dalam menurunkan tekanan darahMcCarron (2010).

Hasil penelitian ini sejalan dengan penelitian jorder R (2010) bahwa tidak ada hubungan asupan kalsium,kalium dan magnesium dengan kejadian hipertensi di kelurahan Bojongsalam.Hasil penelitian ini juga sejalan dengan Nunik Alfiana (2014) bahwa tidak ada hubungan antara konsumsikalsium dan natrium terhadap tekanan darah pada penderita hipertensi rawat inap di RS Tugurejo.

\section{Hubungan Konsumsi Kalium dengan Tekanan Darah Penderita Hipertensi}

Hasil uji statistik menunjukan tidak adanya hubungan yang kuat antara konsumsikalium dengan tekanan darah dengan nilai $p=0,100 \quad(p>0,05)$. Pola konsumsikalium dapat dilihat berdasarkan hasil wawancara menggunakan FFQ semi kuantitatif. Hasil penelitian ini menunjukkan bahwa tidak ada hubungan antara konsumsi kalium dengan tekanan darah dikarenakan pola konsumsi bahan makanan sumber kalium pasien rendah. Hal ini disebabkan 2-3 pasien biasanya hanya mengkonsumsi buah-buahan tertentu yang mengandung kalium tinggi seperti pisang 3-5 kali seminggu,alpukat 1-2 sebulan, dan semangka 2-3 seminggu. pisang 100 gr mengandung 396 mg, alpukat $100 \mathrm{gr}$ mengandung $150 \mathrm{mg}$ dan semangka 100 gr megandung $116 \mathrm{mg}$ kalium,sehingga kebutuhan pasien kurang. Sedangkan kebutuhan kalium pasien normal adalah $4500 \mathrm{mg}$.

Penelitian ini tidak berhubungan karena, pada saat penentuan uji yang akan dilakukan terjadi kesalahan dalam menentukan uji. Seharusnya, uji yang dilakukan menggunakan uji case control, tetapi dilakukan uji cross sectional, sehingga hasil yang didapat tidak adanya hubungan konsumsi kalium dengan tekanan darah penderita hipertensi.

Kalium banyak terdapat dalam bahan makanan mentah atau segar. Proses pemasakan makanan dapat menyebabkan hilangnya kalium dalam bahan makanan dan penambahan garam ke dalam proses pemasakan makanan dapat menyebabkan kandungan natrium dalam makanan tersebut semakin meningkat sehingga dapat terjadi perubahan keseimbangan rasio natrium dan kalium dalam makanan tersebut. Pengaruh kalium terhadap tekanan darah terjadi jika natrium didalam tubuh juga tinggi, tetapi jika asupan natrium normal ataupun kurang maka pengaruh tersebut tidak akan terlihat Rolfes SR (2006).

Penelitian ini juga diperkuat oleh penelitian Jannah M dkk (2013) yang menyatakan tidak ada hubungan antara Konsumsi Natrium Dan Kalium Pada Penderita Hipertensi Dan Normotensi Masyarakat Etnik Minangkabau di Kota Padang Universitas Andalas.

Hasil ini sejalan dengan penelitian Adhyanti (2012), tidak ada hubungan antara faktor risiko pola konsumsi natrium kalium serta status obesitas terhadap kejadian hipertensidi Puskesmas Lailangga.

\section{Hubungan Konsumsi Magnesium dengan Tekanan Darah Penderita Hipertensi}

Hasil uji statistik menunjukan tidak adanya hubungan antara konsumsi magnesium dengan tekanan darah dengan nilai $\mathrm{p}=0,256 \quad(\mathrm{p}>0,05)$.Hasil penelitian menggunakan FFQ semi kuantitatif menunjukkan bahwa hanya sedikit pasien yang mengkonsumsi magnesium contohnya seperti kacang almond, kacang kenari,alpukat, dan kacang mete karena responden jarang mengkonsumsi makanan tersebut dalam sehari-hari. Alpukat dikonsumsi hanya 75 gr (1 buah) mengandung $10 \mathrm{mg}$ dari 1 bulan terakhir yang dilihat dari form FFQ, alpukat yang 
tinggi lemak juga menjadi salah satu faktor responden jarang mengkonsumsinya karena sebagian responden memliki penyakit penyerta seperti jantung dan sebagian responden mengalami obesitas sehingga mereka mengurangi makanan yang menjadi pemicu beberapa penyakit degeneratif seperti jantung,stroke dan hipertensi.

Penelitian ini tidak berhubungan karena, pada saat penentuan uji yang akan dilakukan terjadi kesalahan dalam menentukan uji. Seharusnya, uji yang dilakukan menggunakan uji case control, tetapi dilakukan uji cross sectional, sehingga hasil yang didapat tidak adanya hubungan konsumsi magnesium dengan tekanan darah penderita hipertensi.

Kurang optimalnya fungsi asupan magnesium yang berasal dari makanan dalam menurunkan tekanan darah dapat disebabkan oleh serat, oksalat, fitat dan fosfor yang dapat menghambat absorbsi magnesium di dalam usus halus. Selain itu, faktor stres mental dan fisik juga cenderung menurunkan absorbsi magnesium dan meningkatkan eksresinya Rofles SR (2006).

Penelitian ini sejalan dengan Appel (2009) yang menyatakantidak ada hubungan konsumsi magnesium untuk mencegahdan mengobati hipertensi. Sebagian penelitian klinis menyebutkan suplementasi megnesium tidak efektif untuk menurunkan tekanan darah. Hal tersebut dimungkinkan adanya efek pengggangu dari obat anti hipertensi.

Penelitian ini sejalan dengan penelitian imantini (2013) yang menyatakan bahwa tidak ada hubungan antaranatrium, kalium, dan magnesium terhadap tekanan darah pada penderita hipertensi rawat jalan di rumah sakit pku muhammadiyah surakartadengan tekanan darah sistolik maupun diastolik pada penderita hipertensi.

\section{Hubungan Konsumsi Serat dengan Tekanan Darah Penderita Hipertensi}

Hasil uji statistik menunjukan tidak adanya hubungan antara konsumsi serat dengan tekanan darah dengan nilai $\mathrm{p}=0,80$ ( $>0,05)$.Hasil penelitian menggunakan FFQ semi kuantitatif menunjukan bahwa hanya sedikit pasien yang mengonsumsi buah, sayur, dan kacang-kacangan sebagai sumber serat. Hal ini dikarenakan pasien merasa takut terjadi kenaikan tekanan darah dan pasien juga memiliki penyakit penyerta lainnya seperti gout sehingga pasien membatasi makanan seperti kacangkacangan, daun katu,daun singkong, daun kacang panjang dan lainnya.

Penelitian ini tidak berhubungan karena, pada saat penentuan uji yang akan dilakukan terjadi kesalahan dalam menentukan uji. Seharusnya, uji yang dilakukan menggunakan uji case control, tetapi dilakukan uji cross sectional, sehingga hasil yang didapat tidak adanya hubungan konsumsi serat dengan tekanan darah penderita hipertensi.

Responden juga kurang mengkonsumsi bahan makanan sumber serat seperti kool(hanya 50 gr mengandung 1,4 gr), sawi(50 gr mengandung 1 gr)dan rebung(50 gr mengandung 0,7 gr) serat, konsumsi serat pasien memang kurang dikarenakan penyakit yang diderita responden tidak hanya hipertensi saja,mereka juga memiliki penyakit gastritis sehingga tidak diperbolehkan mengkonsumsi sumber makanan yang mengandung gas dan asam.

Mengkonsumsi serat pangan (dietary fiber) secukupnya setiap hari merupakan cara mudah untuk hidup sehat. buah dan sayuran merupakan gudang komponen penting bagi pencegahan bermacammacam penyakit degeneratif.

Kurangnya konsumsi serat dapat mengganggu proses pencernaan. Mengkonsumsi sumber serat seperti sayuran,buah kacang-kacangan dapat memberikan fungsi ganda bagi tubuh.Perilaku makan di Indonesia 
terutama pada penduduk miskin adalah adanya kecendrungan tingginya konsumsi makanan karbohidrat tinggi dan rendah protein, serat dan vitamin, karena karbohidrat masih merupakan sumber energi yang murah. Sebagian orang mengonsumsi makanan dengan porsi yang jauh lebih besar daripada yang seharusnya, begitu pula sebaliknya (Indrawati, 2009).

Tidak adanya hubungan asupan serat dengan tekanan darah dapat dimungkinkan oleh karena asupan serat sangat berkaitan erat dengan pengaruh asupan zat gizi lainnya, energi total dan aspek gaya hidup.Hasil penelitian ini sesuai dengan dengan penelitian yang dilakukan oleh beilin ( 2008) yang menunjukkan tidak adanya hubungan asupan serat dengan tekanan darah dapat dimungkinkan karena pada penelitian ini konsumsi serat semua subjek kurang dari kebutuhan dan adanya keterbatasan yaitu tidak membedakan jenis asupan serat yang dikonsumsi.

Hasil penelitian ini sesuai dengan penelitian yang dilakukan oleh Sugianty (2008) yang mengatakan tidak ada hubungan antara Konsumsi Karbohidrat, Protein, Lemak, Natrium Dan Serat Dengan Tekanan Darah Pada Lansia. Artikel penelitian. Semarang: Universitas Diponegoro.

Penelitian ini jugasejalan dengan hasil penelitian yang dilakukan oleh Sulistijani (2011) sehat dengan menu berseratyang menunjukkan bahwa tidak adahubungan konsumsi serat dengan tekanan darah.

\section{Hubungan Konsumsi Vitamin D dengan Tekanan Darah Penderita Hipertensi}

Hasil uji statistik menunjukaan tidak adanya hubungan antara asupan vitamin D dengan tekanan darah dengan nilai $\mathrm{p}=0,197$ serta arah hubungannya negatif. Penelitian ini tidak berhubungan karena, pada saat penentuan uji yang akan dilakukan terjadi kesalahan dalam menentukan uji. Seharusnya, uji yang dilakukan menggunakan uji case control, tetapi dilakukan uji cross sectional, sehingga hasil yang didapat tidak adanya hubungan konsumsi vitamin $\mathrm{D}$ dengan tekanan darah penderita hipertensi.

Konsumsi vitamin D dapat dilihat berdasarkan wawancara menggunakan FFQ semi kuantitatif.Hasil penelitian menggunakan FFQ semi kuantitatif menunjukan bahwa hanya sedikit pasien yang mengkonsumsi makanan sumber vitamin D seperti jamur putih dan jamur tiram sebanyak $50 \mathrm{gr}$ (mengandung $2 \mathrm{mcg}$ ) sedangkan dianjurkan konsumsi vitamin sebanyak $15 \mathrm{mcg}$ sehingga kebutuhan pasien belum tercukupi, hal ini disebabkan responden takut terjadi pemicu penyakit lainnya. Di dalam jamur putih dan jamur tiram terdapatergosterol yang merupakan prekursor vitamin D dengan iradiasi sinar ultraviolet dalam jamur tiram putih (Achmad dkk,2011).

FFQ semi kuantitatif menunjukan juga bahwa hanya sedikit pasien yang mengkonsumsi sumber vitamin D seperti ikan tuna atau salmon,karena masyarakat Indonesia masih mengutamakan makanan sumber karbohidrat tinggi dan rendah protein, serat dan vitamin, karena karbohidrat masih merupakan sumber energi yang murah. Sebagian orang mengonsumsi makanan dengan porsi yang jauh lebih besar daripada yang seharusnya, begitu pula sebaliknya (Indrawati, 2009).

Penelitian ini sejalan dengan penelitian Delmi (2011)Pengaruh pola makan terhadap Vitamin D dan MDA plasma laki-laki Etnik Minangkabau yang menunjukan bahwa tidak ada hubungan konsumsi vitamin D dengan kejadian hipertensi.

\section{KESIMPULAN}

Berdasarkan hasil penelitian hubungan pola konsumsi zat gizi makro dan mikro dengan tekanan darah pada penderita hipertensi di poli penyakit dalam RSUD Dr.M.Yunus Kota Bengkulu Tahun 2017 adalah tidak ada hubungan antara pola konsumsi zat gizi makro dan mikro 
dengan tekanan darah pada penderita hipertensi di poli penyakit dalam RSUD Dr.M.Yunus Bengkulu Tahun 2017.

Disarankan perlunya dilakukan kegiatan konsultasi gizi dengan menggunakan leafleat bahan makanan yang mengandung zat gizi makro dan

\section{DAFTAR RUJUKAN}

Adhyanti, Sirajuddin,S., \& Jafar, N. 2012. Faktor risiko pola konsumsi natrium kalium serta status obesitas terhadap kejadian hipertensidi PuskesmasLailangga.http:// repository. unhas. ac.id/ bitstream/ handle/ 123456789/7290/

jurnal_ADHYANTI21107016.pdf?sequenc e=1.Diaksespada tanggal10 Februari2014.

Appel LJ, Brands MW, Daniels SR, Karanja N, Elmer PJ, Sacks FM. Dietary Approaches $O$ Preent And Treat Hypertension : A Scientific Statement From The American Heart Assocoation. Hipetension [Serial Online]. 2006[Dikutip Pada 20 Februari 2009]; 47; 296 - 308. Available From: URL:

HIPERLINKhttp://hyper.ahajournals.otg/c gi/conten/full/47/2/296.

Delmi S, Rahayu S, Astuty P. Pengaruh pola makan terhadap Vitamin D dan MDA plasma laki-laki etnik Minangkabau. MKI. 2004;32:1-5.

Elliott P, Stamler J, Dyer AR, Appel L, Dennis B, Kesteloot H, et al. Association between protein intake and blood pressure: the INTERMAP Study. Arch Intern Med 2006;166: 79-87.

Fauziah Nur Yunaida,Dkk. 2013..Hubungan Asupan Bahan Makanan Sumber Serat, Asupan Lemak Dan IMT Dengan Tekanan Darah Pada Pasien Hipertensi Rawat Jalan Di Rumah Sakit Tugurejo Semarang.

Imantini, 2013. Hubungan Asupan Natrium, Kalium, Dan Magnesium Terhadap Tekanan Darah Pada Penderita Hipertensi Rawat Jalan Di Rumah Sakit Pku Muhammadiyah Surakarta.

Jorder R, Bonaa KH. Calcium from dairy product, vitamin D intake, and blood presssure: the Tromso study. Am J Clin Nurt [ serial online] 2000; 71:1530 Available from : URL :http://www.ajcn.org.

Krummel DA. Medical nutrition therapy in hypertension. In: Mahan K,Escott-Stump S. Krause's food, nutrition, \& diet therapy. 11th edition. Philadelphia: Saunders; 2008. p. $900-18$. mikro kepada responden penderita hipertensi agar responden dapat menjaga pola makan sehingga tidak menyebabkan hipertensi dan Perlunya peran aktif keluarga terkait motivasi dan pola makan responden penyakit hipertensi.

McCarron DA, Morris CD, Young E, Roullet C and Drueke T. Dietary calcium and blood pressure modifying factors in spesific population. Am Jclinn Nurt [ serial online] 2010; 54:215S-19S. Available from : URL :http://www.ajen.org.

McCulloughM, Lin PH. Nutrition, diet and hypertension. In: Coulston AM, Rock CL, Monsen ER, editor. Nutrition in the prevention and treatment of disease. San Diego: Academic Press; 2010.p.305,309,310.

Nunik Alfiana. 2014. Hubungan Asupan Kalsium Dan Natrium TerhadapTekananmDarah Pada Penderita Hipertensi Rawat Inap Di RS Tugurejo Semarang.Skripsi. Program Studi Gizi Fakultas Ilmu Keperawatan Dan Kesehatan.

Rawasiah A.B, Wahiduddin, Rismayanti. 2014. Hubungan Faktor Konsumsi Makanan Dengan Kejadian Hipertensi Pada Lansia di Puskesmas Pattingallong.http://Respository.unhas.ac.i d/bitstream/handle/123456789/10836/A.B ESSERAWASIAHM.MAPPAGILING (Jurnal online. Diakses pada tanggal 25 Mei 2017). 2014.

Rolfes SR, Pinna K, Whitney E. Water and the major mineral. In: Understandingnormal and clinical nutrition. 7th edition. USA: Thomson wadsworth; 2006. P. 41122.

Sugianty. 2008. Hubungan Asupan Karbohidrat, Protein, Lemak, Natrium Dan Serat Dengan Tekanan Darah Pada Lansia. Artikel penelitian. Semarang: Universitas Diponegoro.

Villareal,

$$
\text { D.T., }
$$

Shah,K., Banks,M.R.,Sinacore,D.R.Klein,S.2008.Effe ct of Weight Loss ans Exercise Therapy on Bone Metabolism and Mass in Obese Older Aduls: One-Year Randomized Controlled Trial. J Clin Endocrinol Metab, 93(60 21812187.

Widyaningrum, H 2011. Kitab Tanaman Obat Nusantara. Yogyakarta: Media Pressindo 